\title{
Technological and Operational Mobile Learning Readiness of Secondary Teachers
}

\author{
Alvin Odon Insorio $1,2 *$ (1) \\ ${ }^{1}$ College of Graduate Studies and Teacher Education Research-Philippine Normal University, PHILIPPINES \\ ${ }^{2}$ San Pedro College of Business Administration, PHILIPPINES \\ *Corresponding Author: alvininsorio0413@gmail.com \\ Citation: Insorio, A. O. (2021). Technological and Operational Mobile Learning Readiness of Secondary Teachers. International Journal of \\ Pedagogical Development and Lifelong Learning, 2(1), ep2103. https://doi.org/10.30935/ijpdll/9362
}

\begin{abstract}
Mobile learning is one of the novel directions in delivering the lesson due to the interest of the students towards mobile devices. Before it must be implemented in basic education, the readiness of internal stakeholders must be established first especially the teachers because they act as a middle component between the curriculum and the learners. This study focused on the technological and operational mobile learning readiness of secondary teachers, particularly English, Science, and Mathematics selected using stratified sampling. This was a descriptive design where the survey questionnaire was the research tool for collecting data. It was found out that secondary teachers were much ready in terms of accessibility and affordability of mobile learning. In terms of operational skills, secondary teachers were skilled in operating mobile devices. They were very much ready in reading documents and using mobile as calculators. They believed that mobile learning has a direct effect on learning and they were looking forward to immersing in mobile learning. However, they much need training and support from the institution both help desk and online.
\end{abstract}

Keywords: mobile learning, readiness, secondary teachers

Received: 27 Aug. 2020 Accepted: 3 Oct. 2020

\section{INTRODUCTION}

Mobile learning is considered as the new trend of learning the subject matter with ease utilizing mobile devices like smartphones, tablets, ipads, palmtops, and portable computers. However, Crompton (2013) said that mobile learning has no definite definition at present. So, mobile learning means using any hands-on gadgets for getting information while hanging around anywhere at any time which has strong search connections and affluent interactions. It is vital for this rapidly advancing digital era where the learners always use their gadgets for any purposes such as entertaining, communicating, learning, posting a status, or getting connected with others.

Mobile learning was instinctively mean as electronic learning using a mobile device which is developed and utilized over the years which is seemed like a continuation of electronic learning in response to an answer to the shortage and constraints of electronic learning (Traxler (2005), cited in Guy (2009)). Liu (2009) explained mobile learning as any electronic learning through the utilization of mobile devices for learning. Moreover, mobile learning includes various types of learning that occur as long as the learners use a mobile phone or when the learners make use of the learning possible through mobile devices (O’Malley et al., 2003).
West (2012) believed that teachers play a vital role in implementing a learning process that utilizes mobile learning, which causes them to teach the lessons effectively and promote their moral support. Moreover, teachers play a major role in uplifting quality education employing mobile technology (Fesser, 2013). In other words, Yusofa et al. (2011) stated that if mobile learning will be adopted and implemented, teachers' eagerness and readiness are vital success factors to investigate. On the other hand to Fesser (2013) asserted that teachers require to possess a various and creative chunk of skills and knowledge for the proper utilization of this kind of technology in the classroom setting. Mobile learning, if properly utilized, can improve connections among teachers, administrators, and students.

Lawrence et al. (2008) and Naismith et al. (2004) stated that even though there were broad adult and teen approval of mobile device usage, the mobile learning acceptance from the faculty and support staff in the academe was still small and the manifestations of acceptance are unclear. This calls for another study to establish the readiness of teachers on the said technology use. If the teachers are much ready on mobile learning, successful implementation may arise once the education sector makes policy and guidelines on the utilization of mobile gadgets as learning tools.

In the Philippine setting, mobile learning is at the beginning of its implementation. As learners who own mobile phones usually use them for communicating, entertaining, and other purposes, the teachers' 
readiness before mobile learning is fully used in teaching needs to establish first. The teachers' readiness must be secured to determine if the internal stakeholders are ready to use this kind of technological innovation since there are the implementers of the curriculum. Moreover, the interest of the learners in this era lays in the use of mobile phones, particularly smartphones, it is better to measure the extent to which teachers are ready for mobile learning. Hence, high school subjects that the learners found difficult are English, Science, and Mathematics due to their complexity and nature. So, this study focused on the readiness of secondary teachers as the subject of this study.

\section{LITERATURE REVIEW}

Different researches have been overseen globally on readiness for mobile learning. The study conducted by Abas, Peng, and Mansor (2009) reported that in investigating a readiness for mobile learning someone should include mobile phone ownership, eagerness to buy a mobile phone, and readiness to avail of mobile services. Attewell, SavillSmith, and Douch (2009) advocated that there should be rigorous planning, preparation, and training necessary when utilizing mobile devices. Also, in knowing readiness of students for mobile learning, Trifonova, Georgieva, and Ronchetti (2006) identified important things to consider such as students' attitudes to mobile learning, mobile device ownership, and the use of mobile technology. Stockwell (2008) revealed that one of the factors which prevent the teacher from using mobile phones as learning tools is an attitude, while Cheng and Tsai (2011) identified another factor that can upgrade mobile learning readiness is the support provided for mobile learning by the Higher Education Institution. This research on mobile learning readiness proposed that there are many factors needed to consider in deciding to investigate the possibility of mobile learning implementation.

\section{Technological Readiness for Mobile Learning}

Technological readiness for mobile learning pertains to the degree wherein learners or teachers possess onset to mobile devices and can buy data services that comply or outstrip the technology demand of presently available mobile learning features (Naicker \& Van der Merwe, 2012). This means that to succeed in a mobile environment such as mobile learning, one must not only have access to mobile learning applications and tools but also can afford gadgets and related technologies that can be labeled as technological readiness.

Naismith and Corlett (2006) identified one of the vital considerations for mobile learning - device ownership. Ownership refers to a prerequisite for engagement, where mobile users can go more than what is expected and use with it to investigate its potential (Naismith et al., 2004). Owning a mobile device seems to be the first and foremost valid indicator for technological readiness, but it doesn't mean that the owner is set for mobile learning. The device should have the necessary hardware features and the capacity to run the required mobile learning application (Naicker, 2013).

Corbeil and Corbeil (2011) made a study on students' mobile learning readiness factors. They found out that most student respondents own a mobile phone, but it does not guarantee that owners are prepared for mobile learning and teaching. Although mobile devices must have attributes like internet and email that provide mobile learning, the ability of the gadget to support mobile learning significantly needs to be investigated (Naicker, 2013). Besides, to acquire a mobile device, one must be able to afford and willing to buy such devices and applications. In these times when the mobile device market is already saturated, mobile device makers price their products low to stay in the market (Naicker \& Van der Merwe, 2012), thus, making them within the masses' reach. Aside from the mobile devices, the owner of the device must have the capacity to pay for the apps if the apps are not free, as well as the data connectivity required to run these apps (Naicker, 2013).

\section{Operational Readiness for Mobile Learning}

Another aspect to investigate was operational readiness which pertains to the factors that are considered important for mobile learning other than the accessibility of mobile learning applications and affordability of mobile gadgets and related technologies (Naicker, 2013). Operational readiness includes skills in operating a mobile device, awareness of mobile learning, and attitude towards mobile learning, training, and support they need for the proper administration of mobile learning (Naicker \& Van der Merwe, 2012).

Having a mobile device and being able to afford the necessary software and applications are not enough to say that teacher or student is ready for mobile learning. A teacher willing to engage in mobile learning must have basic knowledge of hardware and software and the necessary skills to operate a mobile device. Connecting to a Wi-Fi hotspot, transferring files using a personal computer going to a mobile device and phone's calculator are only some of the basic skills that can be used for mobile learning.

On the other hand, awareness pertains to the knowledge of the existence of an understanding of a situation or scenario at the present times based on prior information or experience. Different factors are affecting the awareness of teachers for mobile learning. Educational background, school environment, and peer influence are some of these. But as mobile technology advances, there is a growing awareness that this technology will benefit teaching and learning (MacCallum, Jeffrey, \& Kinshuk, 2014).

Teachers' attitudes and perceptions of the use of technology affect their technology use in instruction (Mohammed, 2015). Many pieces of research had been done on attitudes towards mobile learning. Most of them reported that there is a favorable attitude toward the utilization of mobile learning. This good attitude brings the possibility of implementing mobile learning situations in a classroom setting. This was a good indicator of the operational mobile learning readiness of teachers.

In the study of Ozdamli (2012) about students' attitudes towards mobile learning revealed the positive attitude of the students regardless of socio-economic backgrounds. On the other hand, students' attitude towards mobile learning is different based on geographical locations. Hence, Zawacki-Richter, Brown, and Delport (2009) revealed that students perceived some activities which are vital to mobile learning such as staying connected anytime, anywhere; acquiring learning sources; supporting with notifications; sharing with others; and support from the fieldwork. However, teachers must be ready first ahead of their students to make mobile learning more meaningful in the lives of the students.

Capalihan and Pariñas (2017) made a study on technological and operational readiness for mobile learning of mathematics teachers. They found that mathematics teachers are technologically and operationally ready and these attributes that they possess enable them 
to foster a positive attitude towards mobile learning. Thus, their technological and operational readiness is a vital factor that imparts to their mobile learning readiness. In terms of demographic variables, they found out that age and years of teaching experience are correlated to the technological and operational readiness of mathematics teachers.

Different studies have cited the benefits of training and support to make the implementation of mobile learning effective. Educators believed anyone can have the best technology, but what must be utilized with the use of this technology is the existence of technical support (Kukulska-Hulme, 2007). It is a necessity in the educational institutions to secure that technical support is available for the teachers prior to the implementation of mobile learning so that when problems arise they will be addressed directly. Naismith and Corlett (2006) identified institutional support as an important factor for the success of mobile learning.

Corlett et al. (2005) proposed that the success of mobile learning depends on the responsibility of the institution as providing students and teachers with the necessary skills and chances to prosper as mobile learners. Trifonova, Georgieva, and Ronchetti (2006) agreed that the progress of mobile learning is glowing, while big support is needed to cater to the students' big expectancy to guarantee a higher level of utilization of the mobile application in the teaching-learning process.

It is timely and necessary for basic education to assess the readiness of teachers for mobile learning before the administration of this kind of technology (Ford \& Batchelor, 2007). Basole and Rouse (2007) revealed other reasons for a mobile learning readiness assessment. These are mobile learning readiness assessment may provide relevant data on the current mobile technologies for organizations and the manner on how these novel technologies adopt to the needs within the organization. Through this information, management will be able to formulate decisions for improving infrastructure, expenditures, operation, and how to make the technology suitable to the organization's purpose (Basole \& Rouse, 2007)

The dilemma facing in basic education is to find out the mobile learning readiness of their teachers before the implementation of this distance learning method (Trifonova, Geotgieva, \& Ronchetti, 2006). Through this, there is a necessity to assess the prevailing mobile technology readiness of teachers for mobile learning. For mobile learning, the access to internet connectivity of the hardware must be included. This technology readiness factor, if not satisfied, can hinder the mobile learning readiness of the teachers which needs further examination.

The operational readiness which is needed to assess in mobile learning is teachers' attitude towards, awareness of, support, and training needed for mobile learning are unknown to basic education teachers (Naicker \& Van der Merwe, 2012). Moreover, another operational readiness factor for mobile learning to consider is the willingness of faculty to utilize mobile learning. These four operational factors considered show the first required indications for mobile learning readiness which need more investigation (Naicker, 2013). They served as hindrances to mobile learning readiness and for the meaningful implementation of mobile learning. Therefore, the four stated factors must be addressed first.

A literature review has uncovered that few mobile learning readiness studies included one or other mobile readiness factors of teachers and students. These factors are mobile services used, availability of mobile devices, attitude to mobile learning, and affordability which were included in international studies. However, there is no research study has been done on the technological and operational readiness of teachers for mobile learning at a basic education institution. This ensures the need for a new study on mobile learning readiness of secondary teachers in the Philippines wherein mobile devices are common tools used by the students.

\section{Theoretical and Conceptual Frameworks}

The study was anchored on the activity theory as the underlying philosophical approach. It supports a framework for investigating various types of human activities as development processes, with both individual and social levels related to each other simultaneously (Kuutti, 2015). The individual and broad social relations as the basis of mobile learning readiness at basic education are investigated to elaborate the limiting and non-transformative quality of the system regards mobile learning readiness. Also, it concentrates on the localized activity of the system holistically (Uden, 2007). Contextualization pertains to how the components of the activity system come together (Murphy \& Rodriguez-Manzanare, 2008). The activity theory was applied as a lens to see the processes of this study and show ideas into the technological and operational readiness of teachers for mobile learning.

Another theory supporting this study was the theory of planned behavior of Ajzen in 1991. According to Teo (2009), a person's action is determined by his behavioral intentions, where behavioral intention can be divided into three components such as attitude toward behavior, subjective norms, and perceived behavioral control of an individual. One's attitude towards a certain behavior influences the individual's decision either positively or negatively about doing a particular behavior. According to Armitage and Conner (2010), the stronger motivation to execute the behavior is caused by a more favorable attitude towards the behavior. On the other hand, Haggar and Chatzisarantis (2005) defined subjective norm as an individual's perceived expectation that significant others want him to perform a behavior in question. One's confidence, or those who believe that they can perform a specific task, significantly influences his behavior which tends to have a higher intention. In this study, the accessibility and affordability of mobile devices and app served as subjective norms which measure the technological readiness of teachers, attitude and awareness served as individual attitude, while the operational skills and the training and support are the perceived behavioral controls which indicate the operational readiness of the teachers towards mobile learning.

Figure 1 shows the two variables showing the mobile learning readiness of secondary teachers - technological and operational. These variables contribute to how secondary teachers become ready when mobile learning will be implemented in basic education. Technological readiness was measured in terms of accessibility of mobile app and tools, and affordability of mobile gadget and related technologies as perceived by secondary teachers. On the other hand, operational readiness was measured in terms of operational skills, awareness, and attitude towards mobile learning, and training and support for mobile learning. Moreover, the demographic profiles of the respondents were used as grouping variables to determine if a significant difference exists. 
Demographic profile of secondary teachers in terms of:

a. sex,

d. length of teaching experience, and

b. grade leve

e. highest educational attainment

c. subject taught,

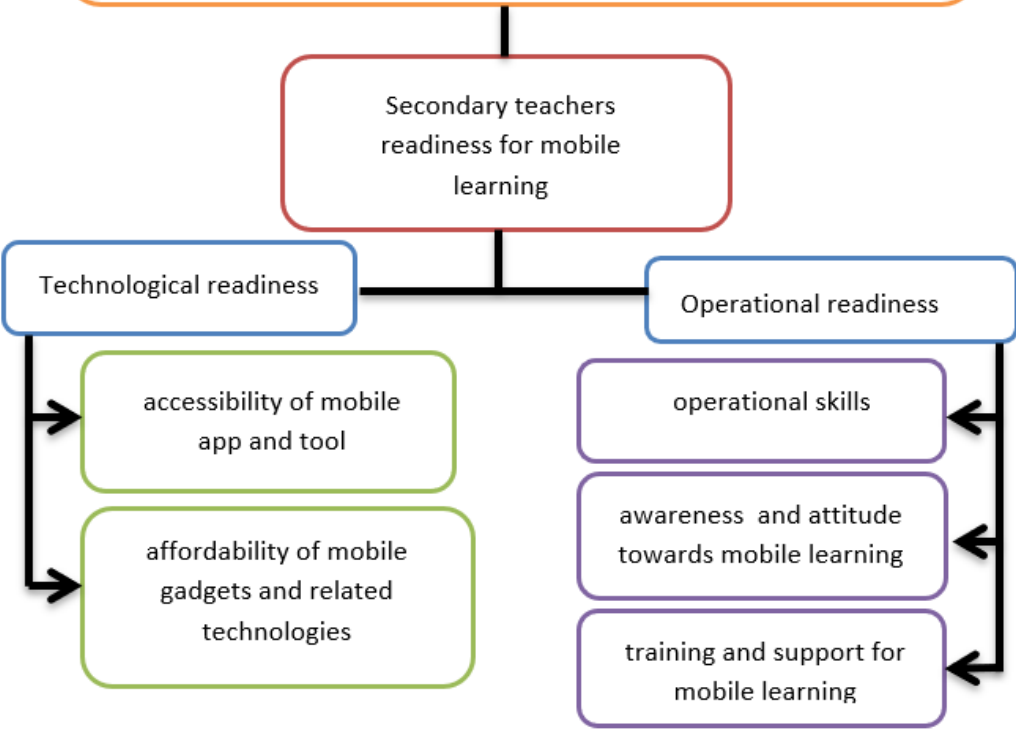

Figure 1. Conceptual Paradigm

Although there are many pieces of research on mobile learning abroad that are gaining momentum, it is still in its infancy in the Philippine setting. There are still several studies that need to be done to be able to keep abreast with technology and enhance the potential of mobile devices for educational use. Also, there is s a need to investigate how mobile devices are presently being applied for education (Naicker, 2013). One way is to secure the readiness of teachers before it will be implemented in the field. The readiness of the school's internal stakeholders will tell how the new paradigm in teaching-learning process will be successful.

For the past ten years, mobile learning is the new trend in solving the challenges faced by the teachers when gaining the interest of the learners in teaching (Capalihan \& Pariñas, 2017). Teachers abroad make use of this device in teaching since the interest of their students lay in mobile activities. Teachers must be ready to adopt and operate the mobile phone ahead of the students to keep them more abreast of the latest technology used by their students. Moreover, mobile readiness has not yet been explored in the Philippine setting, especially in basic education.

This study aimed to determine the technological and operational readiness of Junior and Senior high school teachers in San Pedro, Laguna. Hence, it addressed the following questions: 1 . What is the level of technological readiness of the secondary teachers in terms of a. accessibility of mobile app and tool, and b. affordability of mobile gadgets and related technologies? 2. What is the level of operational readiness of the secondary teachers in terms of a. operational skills for the mobile device, b. awareness and attitude towards mobile, and c. training and support for mobile learning? 3. Are there significant differences in the technological and operational readiness of secondary teachers when they are classified according to sex, subject taught, grade level, highest educational attainment, and length of teaching experience?

\section{METHODOLOGY}

\section{Research Design}

This study was a descriptive survey design because it aims to elicit the technological and operational readiness of the mathematics teachers through a survey. This is the best design to determine how ready are the secondary teachers in terms of mobile learning which was introduced in the Philippines. Calmorin (2010) stated that the data from a descriptive survey when used as a ground in making inferences may help in solving practical problems which is valuable to the researcher rather than principles and laws applied in conducting research. Moreover, the self-report method was utilized to measure the secondary teachers' readiness for mobile learning.

\section{Sampling and Respondents}

The study used 185 public secondary teachers teaching English, Science, and Mathematics in the City of San Pedro, Laguna as respondents for the school year 2018 - 2019. A stratified sampling method was used to determine the target respondents. Moreover, Slovin's formula for sample size at a $3 \%$ margin of error was used to get the exact number of respondents from four public secondary schools in the City of San Pedro, Laguna.

\section{Research Instrument}

The questionnaire was the main instrument of this study with open-ended questions to clarify the answers of the respondents. It was adapted from the work of Parinas and Capalihan (2017) with the reliability of .90 and validated by the expert in the field of mathematics, but some modifications were made to make it suitable to the present study like deleting some items in technological readiness, adding new items for training and support variables, and adding open-ended questions. Zulueta and Perez (2010) stated that the questionnaire is a list of questions with space provided to be answered by the respondents 
especially designed to get facts/information which is directly related to the problem. It is one of the important research tools for data collection.

Since there was a modification made, validation was necessary to be established again (Falatado, 2016). The first draft was presented to the research professor to check the completeness and grammatical structure of the questionnaire. The correction was carefully followed and the second draft was used for content validation. Samosa (2016) said that content validity chiefly targets the test items' originality, suitability, and representation of the items to assess the characteristics or variables to be investigated. This is usually established after the systematic examination of test items by the group of experts on the subject matter. For this reason, 5 experts in the field of English, Science, and Math were consulted to validate the instrument such as education master teachers and headteachers. Their suggestions were considered for the third draft. They rated it with 2.82 which means suitable to use.

After the validity was established, the instrument was pilot tested in Adelina 1 and Southville 3A National High School. A letter of permission was secured first before pilot testing. A total of 10 English, 10 Science, and 10 Mathematics teachers were used to determine its reliability. Using SPSS 23, it was found out Cronbach's alpha was 959 which means highly reliable.

The final draft of the instrument has two parts namely; the profile of the respondents such as name (optional), sex, grade level, subject taught, number of years in teaching, highest educational attainment, number of training in mobile learning and title of the training; and ten items for technological readiness with two options; and twenty-five items for operational readiness with five-point Likert scale. Five items correspond to the accessibility of mobile app and tool, five items correspond to the affordability of mobile gadgets and related technologies, ten items correspond to operational skills, ten items correspond to attitude and awareness toward mobile learning, and five items correspond to training and support which are the variables in the study.

\section{Data Gathering Procedure and Data Analysis}

Permission was secured in the division office to grant authorization to the researcher to carry on the study. After the permission was granted, another letter was prepared for the school head as part of the protocol. Permission from the school heads was elicited and questionnaires were distributed personally to the English, Science, and Mathematics teachers with the help of their department heads. Teachers' consent was elicited first before the distribution of the instrument. Instructions were given to them on how to answer and retrieve the questionnaire. Ample time was given to the teachers to answer. After two weeks, the researcher collected the answered questionnaire and whole-hearted thanks were given to the respondents and headteachers. Answers were tabulated and analyzed using SPSS 23 for computation purposes.

Quantitative data were treated using SPSS 23 for the descriptive and inferential tools. Frequency, percentage, weighted mean, and Multiple Analysis of Variance (MANOVA) were utilized.

\section{Ethical Considerations}

Ethical considerations upon the delivery of the study were followed strictly to protect the rights of each participant especially the rights of the teachers to hide their identity. A letter of permission was signed by the schools' division superintendent and principals before the start of the survey. A letter for the respondents was attached to the survey
Table 1. Demographic Profile of the Respondents

\begin{tabular}{|c|c|c|c|c|c|}
\hline Variables & Frequency & $\%$ & Variables & Frequency & $\%$ \\
\hline \multirow{2}{*}{ Sex } & \multirow{2}{*}{\multicolumn{5}{|c|}{$\begin{array}{c}\text { Highest Educational } \\
\text { Attainment }\end{array}$}} \\
\hline & & & & & \\
\hline male & 52 & 28.11 & Bachelor's degree & 108 & 58.37 \\
\hline female & 133 & 71.89 & MA units & 48 & 25.95 \\
\hline \multirow[t]{3}{*}{ Total } & 185 & 100 & Master's degree & 28 & 15.14 \\
\hline & & & Ph.D. units & 1 & 0.54 \\
\hline & & & Total & 185 & 100 \\
\hline Crade lerel & \multirow{2}{*}{\multicolumn{5}{|c|}{$\begin{array}{l}\text { Years of Teaching } \\
\text { Experience }\end{array}$}} \\
\hline Grade level & & & & & \\
\hline 7 & 49 & 26.49 & $1-5$ & 85 & 45.95 \\
\hline 8 & 34 & 18.38 & $6-10$ & 45 & 24.32 \\
\hline 9 & 42 & 22.70 & $11-15$ & 19 & 10.27 \\
\hline 10 & 34 & 18.38 & $16-20$ & 19 & 10.27 \\
\hline 11 & 20 & 10.81 & $21-25$ & 11 & 5.95 \\
\hline 12 & 6 & 3.24 & $26-30$ & 6 & 3.24 \\
\hline Total & 185 & 100 & Total & 185 & 100 \\
\hline
\end{tabular}

questionnaire to inform them of the purpose of this study. Moreover, the names of the participants were kept secret, and confidentiality of the results was maintained through the use of pseudonyms. Participants' willingness to participate in this study was secured first before the collection of data. Participants were free to answer or not any portion of the questionnaire and their queries were entertained properly. They have a right to withdraw anytime they want and they did not receive any favor just to answer the questionnaire.

\section{RESULTS}

Table 1 shows that most of the respondents were female comprised of $71.89 \%$ and from junior high school comprised of $85.95 \%$. Most of them are new in the teaching profession with a Bachelor's degree comprised of 58.37\%. However, they were inspired to pursue graduate studies to keep abreast of the latest trends in teaching. The title of mobile training and the number of mobile training were not presented because only one respondent has attended before.

Table 2 reveals that almost all of the respondents have a smartphone (90.81) and laptop computer (95.68\%) with memory card expansion and USB on-the-go (OTG) that can read flash drives (83.24\%). These are good indicators of being accessible on mobile learning. It means a high percentage of mobile device ownership shows greater mobile learning support and technological readiness. This is supported by the study of Capalihan and Pariñas (2017) where they identified that teachers have a high percentage of mobile device ownership. Moreover, these findings are similar to the findings of Andaleeb et al. (2010) which affirmed 100\% ownership among Malaysian respondents was seen. The main reason behind this, advised by Iqbal and Qureshi (2012), is the cost of mobile devices was decreased in late time.

In terms of affordability, most of them can afford to buy smartphones and tablets with internet connectivity, but they cannot afford and not willing to buy apps for mobile devices. They look for free apps available on the website because of the cost of application and internet connectivity which is not good for the small salary of teachers.

It can be gleaned on Table 3 that the secondary teachers were very much ready $(\bar{x}=4.37)$ in opening or reading documents on mobile devices and using a calculator on a mobile phone. Moreover, they are 
Table 2. Technological Readiness in terms of Accessibility of Mobile App and Tool and Affordability of Mobile Gadgets and Related Technology

\begin{tabular}{|c|c|c|c|c|}
\hline \multirow{2}{*}{ Statement } & \multicolumn{4}{|c|}{ Frequency } \\
\hline & Yes & $\%$ & No & $\%$ \\
\hline 1. I own a smartphone. & 168 & 90.81 & 17 & 9.19 \\
\hline 2. I own a tablet (an electronic device) & 94 & 50.81 & 91 & 49.19 \\
\hline 3. I own a conventional laptop computer & 177 & 95.68 & 8 & 4.32 \\
\hline 4. I own a smartphone or tablet with internet connectivity & 143 & 77.30 & 42 & 22.70 \\
\hline $\begin{array}{l}\text { 5. My smartphone/tablet has the following features such as memory card expansion and USB on-the- } \\
\text { go (OTG) Phones that can read flash drives. }\end{array}$ & 154 & 83.24 & 31 & 16.76 \\
\hline 6. I can afford to buy a smartphone. & 165 & 89.19 & 20 & 10.81 \\
\hline 7. I can afford to buy a tablet. & 162 & 87.57 & 23 & 12.43 \\
\hline 8. I can afford to buy a smartphone or tablet with internet connectivity. & 153 & 82.70 & 32 & 17.30 \\
\hline $\begin{array}{l}\text { 9. I am willing to buy a smartphone or tablet with internet connectivity or just a portable wifi router } \\
\text { if I already have a smartphone/tablet. }\end{array}$ & 139 & 75.14 & 46 & 24.86 \\
\hline 10. I can afford and willing to buy apps for my mobile device if the app is not free. & 91 & 49.19 & 94 & 50.81 \\
\hline Total & 938 & 100 & 262 & 100 \\
\hline
\end{tabular}

Table 3. Operational Readiness in Terms of Operational Skills

\begin{tabular}{lccc}
\hline Statement & $\overline{\mathbf{X}}$ & SD & Verbal Interpretation \\
\hline 1. I know how to download and install apps for my phone/tablet/laptop. & 4.23 & 1.11 & Much ready \\
\hline 2. I know how to connect web content using a mobile device. & 4.27 & 1.07 & Much ready \\
\hline 3. I know how to download files from the internet (docs, pdf, audio, video, etc). & 4.31 & 1.09 & Much ready \\
\hline 4. I know the proper way of transferring files from PC to mobile devices and vice versa. & 4.27 & 1.08 & Much ready \\
\hline 5. I know how to connect to the wifi router. & 4.29 & .97 & Much ready \\
\hline 6. I know how to use Bluetooth or share it. & 4.43 & .98 & Much ready \\
\hline 7. I know how to open/read documents (word, excel, ppt. pdf) on my mobile device. & 4.74 & .93 & Very much ready \\
\hline 8. I know how to use my mobile device as a calculator. & 4.63 & .67 & Very much ready \\
\hline 9. I know how to find information (usually accessing the web) using my mobile device. & 4.48 & .87 & Much ready \\
\hline 10. I know and am aware of what mobile learning is all about learning through the use of \\
smartphones.
\end{tabular}

Table 4. Operational Readiness in Terms of Awareness and Attitude towards Mobile Learning

\begin{tabular}{lccc}
\hline Statement & $\overline{\boldsymbol{X}}$ & SD & Verbal Interpretation \\
\hline 1. Mobile learning in teaching makes my lesson lively and interesting. & 3.93 & 1.01 & Much ready \\
\hline 2. Mobile learning is the new way of delivering the lesson based on the interest of my students. & 3.89 & 1.04 & Much ready \\
\hline 3. Mobile learning can enhance my teaching experience using the latest mobile application. & 3.95 & .99 & Much ready \\
\hline 4. Mobile learning helps me to download teaching materials easily and share them with my students. & 4.12 & 1.01 & Much ready \\
\hline 5. I affirm that mobile learning has a good effect on learning. & 4.16 & .92 & Much ready \\
\hline 6. I want to see mobile learning as part of the curriculum. & 3.95 & .99 & Much ready \\
\hline 7. I am aiming forward to engaging in mobile learning. & 4.03 & .97 & Much ready \\
\hline 8. I intend to use mobile learning frequently. & 3.68 & 1.05 & Much ready \\
\hline 9. I prefer to use mobile learning for academic support & 3.93 & .96 & Much ready \\
\hline 10. I believe that the use of mobile learning promotes the quality of instruction. & 3.92 & .91 & Much ready \\
\hline Average & $\mathbf{3 . 9 5}$ & $\mathbf{. 9 9}$ & Much ready \\
\hline
\end{tabular}

much ready in searching for information, transferring files from personal computers to mobile devices, downloading files from the internet, installing applications, connecting to $\mathrm{Wi}-\mathrm{Fi}$ router, and Bluetooth. It means they have the operational skills needed for the mobile learning implementation. This is the same finding by Capalihan and Pariñas (2017) where teacher respondents are much ready when it comes to operating mobile devices.

Table 4 reveals that teacher respondents were much aware $(\overline{\mathrm{x}}=$ 3.95) on the possible effect of mobile learning such as it has an impact on learning, helps the teacher to download teaching materials easily and share it with his/her students, enhances teaching experience, makes the lesson lively and interesting, and a novel way of delivering the lesson based on the interest of students. This means secondary teachers are aware of the possible benefits they can get when they use mobile learning. Moreover, they have a positive attitude towards mobile learning because they are looking forward to involving in mobile learning and they see it as part of the curriculum. They are though that using mobile learning will increase the quality of education so they want to use it frequently. These are good indicators of the operational readiness of teachers where the students nowadays are digitally native and much ready for mobile learning. So, if teachers and students are both ready for mobile learning implementation, there is a high chance of effectiveness and efficiency for its proper implementation.

It can be gleaned from Table 5 that public secondary teachers despite being operationally ready; they were still much ready $(\overline{\mathrm{x}}=3.88)$ to attend training/seminar/workshop on the use of mobile learning tools especially on functionality like downloading, sharing, uploading, etc. They are looking for training on the latest mobile application for teaching and learning. Moreover, they were looking for on how to apply mobile learning effectively to the daily routine of teachers. Moreover, they need help desk and online support from the institution for mobile learning. 
Table 5. Operational Readiness in Terms of Training and Support for Mobile Learning

\begin{tabular}{|c|c|c|c|}
\hline Statement & $\overline{\bar{X}}$ & SD & Verbal Interpretation \\
\hline 1. I require help desk support from the institution for mobile learning. & 3.78 & .92 & Much ready \\
\hline 2. I require online support from the institution for mobile learning. & 3.79 & .89 & Much ready \\
\hline 3. I require the training/seminar/workshop on the use of mobile learning tools. & 3.98 & .92 & Much ready \\
\hline $\begin{array}{l}\text { 4. I require the training on mobile handset functionality for mobile learning like file downloading, } \\
\text { sharing, uploading, etc. }\end{array}$ & 3.84 & .93 & Much ready \\
\hline 5. I require training on the latest mobile application for teaching and learning. & 4.00 & .95 & Much ready \\
\hline
\end{tabular}

Table 6. MANOVA for Significant Difference Tests of Between-Subjects Effects

\begin{tabular}{|c|c|c|c|c|c|c|c|}
\hline Source & Dependent Variable & $\begin{array}{l}\text { Type III Sum of } \\
\text { Squares }\end{array}$ & Mean Square & $\mathbf{F}$ & Sig. & $\begin{array}{l}\text { Partial Eta } \\
\text { Squared }\end{array}$ & Verbal Interpretation \\
\hline \multirow{5}{*}{ Grade level } & Accessibility & 1.871 & 1.871 & 1.520 & .221 & .015 & Not significant \\
\hline & Affordability & 5.418 & 5.418 & 2.754 & .100 & .027 & Not significant \\
\hline & Operational Skills & .508 & .508 & .709 & .402 & .007 & Not significant \\
\hline & Awareness and Attitude & 2.304 & 2.304 & 3.270 & .074 & .032 & Not significant \\
\hline & Training and Support & 4.500 & 4.500 & 13.691 & .000 & .120 & Significant \\
\hline \multirow{5}{*}{$\begin{array}{l}\text { Years of Teaching } \\
\text { Experience }\end{array}$} & Accessibility & .428 & .428 & .347 & .557 & .003 & Not significant \\
\hline & Affordability & .065 & .065 & .033 & .856 & .000 & Not significant \\
\hline & Operational Skills & 13.302 & 13.302 & 18.576 & .000 & .157 & Significant \\
\hline & Awareness and Attitude & 2.071 & 2.071 & 2.939 & .090 & .029 & Not significant \\
\hline & Training and Support & .452 & .452 & 1.375 & .244 & .014 & Not significant \\
\hline \multirow{5}{*}{ Subject Taught } & Accessibility & .724 & .362 & .294 & .746 & .006 & Not significant \\
\hline & Affordability & .082 & .041 & .021 & .979 & .000 & Not significant \\
\hline & Operational Skills & .343 & .172 & .240 & .787 & .005 & Not significant \\
\hline & Awareness and Attitude & .134 & .067 & .095 & .909 & .002 & Not significant \\
\hline & Training and Support & .892 & .446 & 1.357 & .262 & .026 & Not significant \\
\hline \multirow{5}{*}{$\begin{array}{c}\text { Highest Educational } \\
\text { Attainment }\end{array}$} & Accessibility & 7.098 & 2.366 & 1.922 & .131 & .055 & Not significant \\
\hline & Affordability & 5.056 & 1.685 & .857 & .466 & .025 & Not significant \\
\hline & Operational Skills & .705 & .235 & .328 & .805 & .010 & Not significant \\
\hline & Awareness and Attitude & .300 & .100 & .142 & .935 & .004 & Not significant \\
\hline & Training and Support & .740 & .247 & .750 & .525 & .022 & Not significant \\
\hline \multirow{5}{*}{ Sex } & Accessibility & .223 & .223 & .181 & .672 & .002 & Not significant \\
\hline & Affordability & .954 & .954 & .485 & .488 & .005 & Not significant \\
\hline & Operational Skills & .036 & .036 & .051 & .822 & .001 & Not significant \\
\hline & Awareness and Attitude & .006 & .006 & .009 & .925 & .000 & Not significant \\
\hline & Training and Support & .280 & .280 & .851 & .358 & .008 & Not significant \\
\hline \multirow{5}{*}{$\begin{array}{c}\text { Subject Taught } * \\
\text { Highest Educational } \\
\text { Attainment }\end{array}$} & Accessibility & 14.366 & 3.592 & 2.917 & .025 & .104 & Significant \\
\hline & Affordability & 1.689 & .422 & .215 & .930 & .009 & Not significant \\
\hline & Operational Skills & 4.191 & 1.048 & 1.463 & .219 & .055 & Not significant \\
\hline & Awareness and Attitude & 1.253 & .313 & .444 & .776 & .017 & Not significant \\
\hline & Training and Support & 1.507 & .377 & 1.146 & .339 & .044 & Not significant \\
\hline \multirow{5}{*}{ Subject Taught * Sex } & Accessibility & 6.566 & 3.283 & 2.666 & .074 & .051 & Not significant \\
\hline & Affordability & 5.154 & 2.577 & 1.310 & .274 & .026 & Not significant \\
\hline & Operational Skills & 2.439 & 1.220 & 1.703 & .187 & .033 & Not significant \\
\hline & Awareness and Attitude & 2.750 & 1.375 & 1.951 & .148 & .038 & Not significant \\
\hline & Training and Support & .976 & .488 & 1.485 & .231 & .029 & Not significant \\
\hline \multirow{5}{*}{$\begin{array}{l}\text { Highest Educational } \\
\text { Attainment } * \text { Sex }\end{array}$} & Accessibility & 9.898 & 4.949 & 4.019 & .021 & .074 & Significant \\
\hline & Affordability & 19.400 & 9.700 & 4.931 & .009 & .090 & Significant \\
\hline & Operational Skills & 1.980 & .990 & 1.383 & .256 & .027 & Not significant \\
\hline & Awareness and Attitude & 1.068 & .534 & .758 & .471 & .015 & Not significant \\
\hline & Training and Support & 1.851 & .925 & 2.816 & .065 & .053 & Not significant \\
\hline \multirow{5}{*}{$\begin{array}{l}\text { Subject Taught* } \\
\text { Highest Educational } \\
\text { Attainment } * \text { Sex }\end{array}$} & Accessibility & 10.584 & 3.528 & 2.865 & .040 & .079 & Significant \\
\hline & Affordability & 7.276 & 2.425 & 1.233 & .302 & .036 & Not significant \\
\hline & Operational Skills & 1.358 & .453 & .632 & .596 & .019 & Not significant \\
\hline & Awareness and Attitude & 2.367 & .789 & 1.120 & .345 & .033 & Not significant \\
\hline & Training and Support & 1.268 & .423 & 1.286 & .283 & .037 & Not significant \\
\hline
\end{tabular}

Table 6 shows that the significant difference exists in training and support needed for mobile learning as perceived by the respondents when they were classified under grade level. Also, a significant difference lies in operational skills based on the years of teaching experience. However, there's no significant difference in terms of the highest educational attainment. These findings corroborate the 
Table 7. A Least Significant Difference in Training and Support when the Respondents were Grouped According to Grade Level

\begin{tabular}{|c|c|c|c|c|c|}
\hline & $\begin{array}{l}\text { Grade } \\
\text { level }\end{array}$ & $\begin{array}{c}\text { Grade } \\
\text { level }\end{array}$ & $\begin{array}{c}\text { Mean } \\
\text { Difference }\end{array}$ & Std. Error & Sig. \\
\hline \multirow{15}{*}{ LSD } & \multirow{5}{*}{7} & 8 & -.21222 & .17011 & .215 \\
\hline & & 9 & -.31238 & .16051 & .054 \\
\hline & & 10 & -.13631 & .17011 & .425 \\
\hline & & 11 & $-.62697^{*}$ & .20202 & .002 \\
\hline & & 12 & $-1.12813^{*}$ & .32574 & .001 \\
\hline & \multirow{4}{*}{8} & 9 & -.10017 & .17641 & .571 \\
\hline & & 10 & .07591 & .18520 & .683 \\
\hline & & 11 & -.41476 & .21487 & .056 \\
\hline & & 12 & $-.91591^{*}$ & .33387 & .007 \\
\hline & \multirow{3}{*}{9} & 10 & .17608 & .17641 & .320 \\
\hline & & 11 & -.31459 & .20735 & .132 \\
\hline & & 12 & $-.81574^{*}$ & .32908 & .015 \\
\hline & \multirow{2}{*}{10} & 11 & $-.49066^{*}$ & .21487 & .024 \\
\hline & & 12 & $-.99182^{*}$ & .33387 & .004 \\
\hline & 11 & 12 & -.50115 & .35120 & .156 \\
\hline
\end{tabular}

*. The mean difference is significant at the 0.05 level

findings of the study of Xue et al., (2012) and Marcial (2014) who found out that educational attainment is a predictor of a mobile phone-based intervention. The technological readiness of the younger teachers may be attributed to being on the borderline between a digital native and a digital immigrant and the requirement of the Department of Education (DepEd) for new teachers to be computer literate before being hired.

Moreover, the subject taught and highest educational attainment has interaction effect on accessibility for mobile app and tools. It means the low educational attainment and the hard subject need much training and support for the proper mobile learning implementation. In addition, there is an interaction effect of the highest educational attainment and sex on accessibility and affordability of mobile learning. It means female respondents with low educational attainment have less accessibility and affordability of mobile learning. Moreover, subject taught, highest educational attainment and sex have an interaction effect on accessibility. It shows that females with low educational attainment and teaching Science or Math have low access to mobile learning.

Table 7 reveals that there is a significant difference in training and support needed by teacher respondents when they are classified according to grade level. The difference lies between grade 7 and 11, grade 7 and 12, grade 8 and 12, grade 9 and 12 , grade 10 and 11 , and grade 10 and 12. It means the lower grade level needs much training and support for mobile learning. They must be much assisted and guided by the help desk from the institution.

\section{DISCUSSION}

In line with activity theory, secondary teachers were capable of operating mobile devices to download, upload, and view lessons on mobile devices following rules in performing those tasks which they think will transform into the result of enhanced academic outcomes on the part of their students. Moreover, tools such as mobile devices, applications, and networks served as the way in improving their delivery mode of a lesson based on the interest of learners. Their ownership of mobile devices and affordability to purchase those devices make them technologically ready for the implementation of mobile learning.
In the lens of the theory of planned behavior, the positive attitude and awareness of secondary teachers influence their intentions to utilize mobile learning in school. Moreover, those who believe that they can perform a specific task significantly influence his behavior which creates have higher intention. The subjective norms in this study served as the indicator of technological readiness of secondary teachers. They were much accessible and can afford to have mobile devices. While the perceived behavioral control in terms of operational skill, secondary teachers were much ready to operate the mobile devices because they felt the need to become digitally immigrant to adjust to the need of digital native - students.

Teacher respondents require themselves to participate in the latest application for teaching and learning. Also, they are eager to be trained for the proper use of mobile devices, strategies, and techniques for using mobile apps. They look forward on how to make the mobile app suitable for their students which they are hoping to teach when mobile learning training will be conducted because they think that this is the most important part of the professional development training program that the DepEd trainers can give. Moreover, they seek help desk and online support from the institution where they are if mobile learning is implemented.

\section{CONCLUSIONS AND RECOMMENDATIONS}

To sum up, secondary teachers were much ready technologically. Most of them own mobile devices like smartphones and laptop computers. They were also operationally much ready. They could perform basic operations in mobile devices such as opening and reading documents, downloading and uploading files, connecting to the internet. They are much aware of the benefits of mobile learning and have a positive attitude towards it. However, they need training and support for the implementation of mobile learning. Those training programs must pay attention to the proper use of mobile devices in delivering the lesson and creating mobile applications which are the need of secondary teachers if ever the DepEd official plan to conduct the professional training program. In addition, school administrators must extend their assistance to teachers when mobile learning is implemented. They served as stewards of the institution securing a supportive environment for effective learning to happen in school.

The limitation of the study lies in the use of a cross-sectional design where one-time data collection was utilized. It is better if the data were collected longitudinally, so that pattern and true answers may be elicited. Also, this study used a quantitative approach. Experiences in using mobile devices in teaching were not included in this study. Similarly, their reaction on how mobile learning will be implemented was not included here. It is suggested that future research may do a mixed-methods design to get more meaningful and accurate data. Another limitation is the use of a self-report method where the respondents rate themselves based on the items of the questionnaire. It is better to triangulate the data to establish the accuracy, but it was not utilized in this study due to the limited time allotted. 


\section{REFERENCES}

Abas, Z. W., Peng, C. L., and Mansor, N. (2009). A study on learner readiness for mobile learning at Open University Malaysia. Paper presented at the IADIS International Conference Mobile Learning. Barcelona, 26-28 February 2009.

Ajzen, I. (1991). The theory of planned behavior. Organizational Behavior and Human Decision Processes, 50(2), 179-211. https://doi.org/10.1016/0749-5978(91)90020-t

Andaleeb, A. A., Idrus, R. M., Ismail, I., \& Mokaram, A. K. (2010). Technology readiness index (TRI) among USM distance education students according to age. World Academy of Science, Engineering and Technology, 39, 1039-1042. Retrieved from www.citeseerx.ist.psu. edu/viewdoc/download?doi=10.1.1.309.3491\&re=rep1\&type=pdf

Armitage, C., \& Conner, M. (2010). Efficacy of the theory of planned behavior: A meta- analytic review. British Journal of Social Psychology. 40(4), 471-499. https://doi.org/10.1348/01446660 1164939

Attewell, J., Savill-Smith, C., \& Douch, R. (2009). The impact of mobile learning: examining what it means for teaching and learning. London: Newnorth Print Ltd.

Barker, A., \& Krull, G., \& Mallinson, B. (2009). A proposed theoretical model for m-learning adoption in developing countries. In mLearn 2005 - 4th World Conference on mLearning Cape Town.

Basole, R., \& Rouse, W. B. (2007). Mobile enterprise readiness and transformation. In: Encyclopedia of Mobile Computing and Commerce. Hershey, PA: Idea Group Inc. IGI. https://doi.org/10.4018/978-159904-002-8.ch079

Calmorin, L. P. (2010). Research and Statistics with Computer. Mandaluyong City: National Bookstore.

Capalihan, J., \& Pariñas, T. (2017). Mathematics teachers' technological and operational readiness for mobile learning. Philippine Normal University.

Cheng, K., \& Tsai, C. (2011). An investigation of Taiwan University students' perceptions of online academic help-seeking, and their web-based learning self-efficacy. Internet and Higher Education, 14(3), 150-157 https://doi.org/10.1016/j.iheduc.2011.04.002

Corbeil, J., \& Corbeil, M. (2011). Are we ready for mobile learning now? 2007 Mobile Learning Predictions Revisited. Issues in Information Systems. Retrieved from http://iacis.org/iis/2011/142-152AL2011-1680.pdf

Corlett, D., Sharples, M., Bull, S., \& Chan, T. (2005). Evaluation of a mobile learning organizer for university students. Journal of Computer Assisted Learning, 21(1), 162-170. https://doi.org/10.1111/j.1365-2729.2005.00124.x

Crompton, H. (2013). A historical overview of mobile learning: Toward learner-centered education. In Z. L. Berge \& L. Y. Muilenburg (Eds.), Handbook of mobile learning. Florence, KY: Routledge. Retrieved from https://www.academia.edu/5601076/ A_historical_overview_of_mobile_learning_Toward_learnercentered_education

Cruz, I. (2015). Technology in K to 12. The Philippine Star. Retrieved from http://www.philstar.com/education-and-home/2015/ technology-k-12
Faltado, R. E. III. (2016). Practical Research 2: Quantitative Research. Quezon City, Philippines: Lorimar Publishing, Inc.

Fesser, J. (2013). MLearning is not Elearning on a mobile device. Retrieved from http://floatlearning.com/2013/05/mlearning-is-notelearning-on-a-mobile-device-part-deux/

Ford, M., \& Batchelor, J. (2007). From zero to hero-is the mobile phone a viable learning tool for Africa? Paper presented at the $3 r d$ International Conference on Social and Organizational Informatics and Cybernetics Orlando, Florida, USA, 12-15 July 2007.

Guy, R. (2009). The Evolution of Mobile Teaching and Learning. Santa Rosa. California: Informing Science Press.

Hagger, M. S., \& Chatzisarantis, N. L. D. (2005). First- and higherorder models of attitudes, normative influence, and perceived behavioural control in the theory of planned behaviour. British Journal of Social Psychology, 44, 513-535. https://doi.org/10.1348/014466604X16219

Iqbal, S., \& Qureshi, I. A. (2012). M-learning adoption: A perspective from a developing country. The International Review of Research in Open and Distance Learning, 13(3), 147-164. https://doi.org/10.19173/irrodl.v13i3.1152

Kukulska-Hulme, A. (2007). Mobile Usability in Educational Contexts: What have we learned? International Review of Research in Open and Distance Learning, 8(2), 1-16. https://doi.org/10.19173/ irrodl.v8i2.356

Kuutti, K. (2015). Activity Theory as a potential framework for humancomputer interaction research. In Context and consciousness: activity theory and human-computer interaction (pp. 17-44). https://doi.org/10.7551/mitpress/2137.003.0006

Lawrence, E., Bachfischer, A., Dyson, L. E., \& Litchfield, A. (2008). Mobile learning and student perspectives: An Reality check! Paper presented at the 7th International Conference on Mobile Business, Barcelona, Spain. https://doi.org/10.1109/ICMB.2008.33

Liu, X. (2009). Applied research on mobile learning in foreign language learning. In: Proceedings of Second International Conference on Education Technology and Training (pp. 309-312). New York, IEEE Press. https://doi.org/10.1109/ETT.2009.35

MacCallum, K., Jeffrey, L., \& Kinshuk. (2014). Factors impacting teachers' adoption of mobile learning. Journal of Information Technology, 13, 141-162. https://doi.org/10.28945/1970

Marcial, D. (2014). Teacher education perceptions of a proposed mobile classroom manager. The IAFOR Journal of Education Technologies \& Education Special Edition, 3(SE), 13-29. https://doi.org/10.22492/ije.3.se.01

Mohammed, Y. (2015). Science Teachers' Attitudes Towards Using ICT and Mobile Learning Technologies in Malaysian Schools. European Journal of Interdisciplinary Studies, 3(1), 187-196. https://doi.org/10.26417/ejis.v3i1.p187-196

Murphy, E., \& Rodriguez-Manzanares, M. A. (2008). Using activity theory and its principle of contradictions to guide research in educational technology. Australasian Journal of Educational Technology, 24(4), 442-457. https://doi.org/10.14742/ajet.1203

Naicker N. (2013). The technology and operational readiness of students for mobile learning at a South African higher education institution. Retrieved from http://uri.unisa.ac.za/bitstream/handle/ dissertation-naicker.pdf 
Naicker, N. K., \& Van der Merwe, T. M. (2012). Mobile learning in higher education: A study of the technology readiness of Students at a South African Higher Education Institution. Paper presented at the 14th Annual Conference on World Wide Web Applications. Durban, 7-10 November 2012.

Naismith, L., \& Corlett, D. (2006). Reflections on success: $A$ Retrospective of the Mlearn Conference Series 2002-2005. mLearn 2006: Across generations and cultures, 2006, Banff, Canada. 29 p. ffhal$00197366 \mathrm{f}$

Naismith, L., Lonsdale, P., Vavoula, G., \& Sharples, M. (2004). Mobile technologies and learning. Retrieved January 3, 2018, from http://archive.futurelab.org.uk/resources/publications-reportsarticles/literature-reviews/Literature-Review203

O’Malley, C., Vavoula, G., Glew, J. P., Taylor, J., Sharples, M., \& Lefrere, P. (2003). Guidelines for learning/teaching/tutoring in a mobile environment. Retrieved from https://hal.archivesouvertes.fr/hal-00696244/document

Ozdamli, F. (2012). Pedagogical framework of m-learning. ProcediaSocial and Behavioral Sciences, 31, 927-931. https://doi.org/10.1016/j.sbspro.2011.12.171

Park Y (2011). A pedagogical framework for mobile learning: Categorizing educational applications of mobile technologies into four types. The International Review of Research in Open and Distributed Learning, 12(2), 78-102. https://doi.org/10.19173/irrodl.v12i2.791

Samosa. R. (2016). Digging up the principles and concepts of practical research - A quantitative approach. Mandaluyong City: National Bookstore inc.

Stockwell, G. (2008). Investigating learner preparedness for and usage patterns of mobile learning. ReCALL, 20(3), 253-270. https://doi.org/10.1017/S0958344008000232
Teo, T. (2009). Modeling technology acceptance in education: A study of pre-service teachers. Computers \& Education, 52(2), 302-312. https://doi.org/10.1016/j.compedu.2008.08.006

Trifonova, A., Georgieva, E., and Ronchetti, M. (2006). Determining students' readiness for mobile learning. In: Proceedings of 5th WSEAS International Conference on E-ACTIVITIES. Venice, Itlay, 2022 November.

Uden, L. (2007). Activity theory for designing mobile learning. International Journal of Mobile Learning and Organisation, 1(1), 81102. https://doi.org/10.1504/IJMLO.2007.011190

West, M. (2012). Mobile learning for teachers global themes, Paris, France, United Nations Educational, Scientific and Cultural Organization (UNESCO). Retrieved from http://unesdoc.unesco.org/images/ 0021/002164/216452e.pdf

Xue, L., Yen, C. C., Chang, L., Chan, H. C., Tai, B. C., Tane, S. B., Duhf, H. B. \& Choolani, M. (2012). An exploratory study of aging women's perception on access to health informatics via a mobile phone-based intervention. International Journal of Medical Informatics, 81(9), 637-648. https://doi.org/10.1016/ j.ijmedinf.2012.04.008

Yusofa, A. M., Aziz b, K. A., Daniel E. G. S., Lowd, W. Y., \& Paule, A. (2011). Teachers' perception on mobile learning for special needs learner: A Malaysian case study. Paper Presented at the APAC MLearning Conference, Bandung Indonesia.

Zawacki-Richter, O., Brown, T., and Delport, R. (2009). Mobile learning: From single project status into the mainstream? European Journal of Open, Distance and E-Learning, 1(1). Retrieved from https://www.learntechlib.org/p/52125/

Zulueta, F., \& Perez, J. (2010). Methods of research, thesis writing and applied statistics. Mandaluyong City: National Bookstore Inc. 